\title{
Sustainability is the issue of human capital investments
}

ZRINKA ŽIVKOVIĆ MATIJEVIĆ, MSc*

Conference introductory note

https://doi.org/10.3326/pse.42.2.7

\footnotetext{
* Received: February 20, 2018

Accepted: February 21, 2018

A conference introductory note given at the conference "Public Sector Economics 2017 - Public investment: catalyst for sustainable growth" organized by the Institute of Public Finance and Friedrich-Ebert-Stiftung in Zagreb on November 3, 2017.
}

Zrinka ŽIVKOVIĆ MATIJEVIĆ

Head of Research Department, Raiffeisenbank Austria d.d., Magazinska cesta 69, 10000 Zagreb, Croatia e-mail: zrinka.zivkovic-matijevic@rba.hr 
1 WERE WE INDEED SO SUCCESSFUL?

Even without the official 2017 budget statistics, informally we can say that even in the year 2017 Croatia continued the fiscal consolidation. In the worst case scenario the balance of general government budget landed in a historically low deficit (or, according to the Ministry of Finance, saw a mild surplus), and the public debt proceeded to shrink as compared to the GDP. In addition to the continued economic growth, for the first time since 2004 Croatia was awarded a long-term rating upgrade. However, this year at least, the rating will remain a category below investment grade, clearly recalling the deeply rooted weaknesses and the still high indebtedness. The story of fiscal consolidation in the Republic of Croatia is seemingly rather a nice one, but unquestionably it also raises quite a number of questions. One of the key issues is the extent to which the fiscal consolidation is a consequence of cyclical factors, and the extent to which it resulted from purposefully implemented economic policy measures. Or, in other words, how much did the outer factors impact the recovery, and how much was this a consequence of the structural changes we ourselves implemented in the long-lasting recession in order to raise the potential growth rate, sustainability and resilience of the overall economy?

As regards revenues, the above-expected contribution in the past year was most likely recorded in revenues from indirect taxes (VAT) and social contributions, which was the outcome of growth in economy and employment. Total revenues from direct taxes rose, probably due to an increase in inflows from profit tax, whereas inflows from income tax decreased in keeping with the tax reform.

The discouraging fact, however, is that the growth and the consequential inflow in the government treasury is very much based on tourism, which heightens the sensitivity and vulnerability of the overall economy and budget. In the structure of Croatian services nearly three quarters are linked to tourism. When it is compared to other EU member states with regard to the share of knowledge intensive services exports in overall services exports, Croatia is at the bottom end of the list with a share of less than $20 \%$. The current services structure in the Croatian economy looks more like that of small, island states, and exposes the whole economy to excessive negative risks, should adverse geopolitical events occur. A similar, comparatively unfavourable structure is present in the case of foreign trade in goods. That is, in the exports structure, export of medium and high technology products is relatively modest, at around 38 percent.

This is the consequence of a historically inadequate use of the basic growth sources - of labour, primarily. Amid the conditions of an increasingly faster and more demanding global environment, structural problems of the labour market, linked also to inadequate adjustment of the educational system, have reduced the growth potentials. Furthermore, the very weak and slow progress in technology, partially caused by problems in the educational systems, scientific research, public administration and relatively poor R\&D investments, imposes the necessity of stronger, 
more resolute and faster structural changes because otherwise Croatia will continue to lag behind most European countries.

As regards the public expenditures, probably we will not witness any material changes structurally. On one hand, the fall in government borrowing costs and the resulting fall in interest costs is heartening, but investment costs are still on the downslide, thus still maintaining the absence of any stronger driving force in this field. Moreover, the government's investment activity in 2017, as compared to 2016, has slowed down. On account of last year's adjustment of pensions, social benefits increased, whereas the wage talks between the Government and the government services unions and their implementation on the public services staff affected growth of budget expenses in the compensation of employees item.

\section{2 ...AND WHAT ABOUT THE (LONG-TERM) OUTLOOK...}

The short-term outlook for economic growth and fiscal consolidation in the sense of reining in deficit and reducing public debt seems favourable. Nevertheless, mid-term to long-term prospects indicate very explicitly that vulnerabilities were not eased, let alone resolved. As said before, the appetites of various interest groups directed mostly at increasing material rights (which usually inflate the current public expenditure whereas future investments remain at the back of the mind) are rising already. Along with exports, investments are the most appreciated source of growth, but when speaking of investments, the $21^{\text {st }}$ century stresses a new dimension that has to be considered. All advanced countries have realised that in the modern society, despite the ever increasing automation and digitization of business, human capital is the most valuable resource of any society, and investments in human capital (along with investments in research and development) are one of the key factors in increasing prosperity. What is more, return on human capital investments is rather high, and contrary to the populist viewpoint, return on these investments is materialized only in the long run. Nevertheless, it is evident that human capital accumulation created over time is material for raising productivity, crucial for economic growth and inevitable in creating a more resilient economy. Both in its essence and according to economic theory, human capital represents a major resource that to a substantial extent determines the direction and the dynamics of any country's development. Human capital is shaped and assembled from the early childhood years throughout the educational system and lasts, or should go on, throughout a lifetime. As most education in the phase of formal schooling is financed by public money, the education system should be of special interest to the creators of economic policy also in the financial (short-term) sense. However, much more important than the actual (public) expenditure for education is the issue of efficacy in spending the money because, in the end the efficiency sets the successfulness of return on a particular investment.

In the context of measuring the efficacy of using (public) money on education and achieving public policy goals, various quantitative and qualitative measures are applied, as well as the measures of participation in the labour market and/or in the 
system of education and life-long learning. In order to assess the overall performance of (public) money spending policies with regard to education, it is necessary to review all three aspects.

The most common quantitative measure is the level of involvement in tertiary education, whereas pupils' PISA ${ }^{1}$ tests are used for quality, or assessment of cognitive abilities. Finally, not less important in measuring the value of spending (public) money on education is the participation of young people in the labour market after finishing their schooling. A higher education level, but also one of better quality, provides individuals with higher employability, faster learning of required knowledge and skills and, in the end, the ability to have higher earnings and better living standard. On the other hand, the society as a whole prospers not only due to a higher long-term growth rate but also due to better resilience to the inevitable downward slides of the economic cycle. Hanushek and Woessmann (2007) confirms the positive correlation of improved results (of cognitive skills) in the PISA tests to real annual GDP growth rate, and raising the success of the young people who are not involved in the education system is considered especially significant.

However, analysis of quantitative and qualitative indicators of investment in human capital and all analyses of labour market participation demonstrate that Croatia belongs to the group of the European Union countries at the bottom of the list. Moreover, European Commission (2017) analyses confirm that the same amount of money could generate a markedly better result.

The importance of investing in human capital gains in relevance especially when exceptionally unfavourable demographic trends and population aging are taken into consideration. Not only do neglecting human capital and ignoring modern demographic trends smother the already low growth potentials, they also put a great deal of pressure on public finances, especially through the health and pension system.

\section{CONCLUSION}

To rewind the story to the beginning, we can only hope that fiscal metrics improvement will not encourage repetition of past expenditure models. A wider and more long-term view warns of suboptimal use of the most valuable resource of our society - its human capital. The numerous reforms directed at improving the educational system and the labour market, besides being implemented slowly, now seem outmoded and inappropriate because they do not develop the skills and knowledge adjusted to the skyrocketing progress of technology. Continuous learning and developing of skills are a prerequisite for strengthening competitiveness, increasing productivity and innovativeness, without which no individual and no society as a whole can expect any increase, as well as any sustainability, in the standard of living.

${ }^{1}$ PISA - Programme for International Students Assessment - assesses the extent to which 15-year-old students, near the end of their compulsory education, have acquired key knowledge and skills that are essential for full participation in modern societies. 


\section{REFERENCES}

1. European Commission, 2017. Investment in Human Capital: Assessing the Efficiency of Public Spending on Education. Bruxelles: European Commission.

2. Hanushek, E. and Woessmann, L., 2007. The Role of Education Quality in Economic Growth. World Bank Policy Research Working Paper, No. 4122. Available at: $<$ https://openknowledge.worldbank.org/bitstream/handle/10986/ 7154/wps4122.pdf? sequence=1\&isAllowed=y $>$

3. OECD, 2017. PISA 2015 Assessment and Analytical Framework. Paris: OECD. https://doi.org/10.1787/9789264281820-en 